\author{
ELSA BORGES DA SILVA $(*)\left(^{\circ}\right)$ - MARTA MAIA - MARIA SANTOS - AMÂNDIO CRUZ $(* *)$ \\ MANUEL BOTELHO $(* *)$ - JOSÉ CARLOS FRANCO $(*)$ - HENRIQUE RIBEIRO $(* *)$ - ANTÓNIO MEXIA (**)
}

\title{
PARTHENOLECANIUM CORNI (BOUCHÉ) (HEMIPTERA COCCIDAE) IN VINEYARDS IN PORTUGAL: MORPHOLOGY, SEASONAL DEVELOPMENT, LIFE CYCLE AND REPRODUCTION $\left({ }^{1}\right)$
}

\author{
(*) CEF-Forest Research Center, Instituto Superior de Agronomia, Universidade de Lisboa, Tapada da Ajuda 1349-017 \\ Lisboa, Portugal. \\ (**) LEAF-Linking, Landscape, Environment, Agriculture and Food, Instituto Superior de Agronomia, Universidade de \\ Lisboa, Tapada da Ajuda 1349-017 Lisboa, Portugal. \\ $\left({ }^{\circ}\right)$ Corresponding author: elsasilva@isa.ulisboa.pt
}

Silva E.B., Maia M., Santos M., Cruz A., Botelho M., Franco J.C., Ribeiro H., Mexia A. - Parthenolecanium corni (Bouché) (Hemiptera Coccidae) in vineyards in Portugal: morphology, seasonal development, life cycle and reproduction.

Due to the type of damage associated with scale insects of genus Parthenolecanium sp. (Hemiptera Coccidae) on vineyards and the increase of its importance, these pests have been studied in central region of Portugal. We addressed the following objectives: i) identification and morphological characterization of soft scales occur in vineyards and the parasitoids associated; ii) seasonal development and life cycle; iii) reproduction. The examined scale were identified as Parthenolecanium corni (Bouché, 1844), despite the existence of some morphological differences and fertility levels recorded in the two regions studied. Coccophagus lycimnia (Walker, 1839) (Hymenoptera Aphelinidae) and Metaphycus dispar (Mercet, 1925) (Hymenoptera Encyrtidae) parasitize the studied P. corni. Based on laboratory and field bioassays, some aspects of morphology as well the seasonal development, life cycle and reproduction are presented.

KEY WORDS: Soft scale insect, european fruit lecanium, parasitoids.

\section{INTRODUCTION}

Parthenolecanium corni (Bouché) (Hemiptera, Coccidae), the European fruit lecanium, is widespread in various wine-producing countries such as Germany, Argentina, Chile, Spain, France, Greece, Italy, USA and also in Central Asia (STATHAs et al., 2003; AfOnso et al., 2004; DAANE et al., 2008). It is also known that P. corni are highly polyphagous; this species maintains a relationship with about 350 known species of host plants globally (BENDov, 1993; CABI, 2016).

The morphology of the adult female of $P$. corni, including size and color is differed between host plants and influenced by the geography, environmental conditions and time of year (Williams, 1997; MarotTA, 1997). Due to the high degree of variation of shape, size and color that females of $P$. corni can display, it was even recognized by DANZIG (1997) as several closely related species ("the corni-complex"). In fact, the review by DANZIG (1997) for P. corni showed extreme variation in its external appearance, while also varies widely in microscopic characters. Furthermore, added the difficulty of detecting this species because the young adult females before the laying stage and nymphs of the second and thirdinstars typically occur on the branches, camouflage in the color thereof, that is, brownish irregular patches, making them difficult to detect in field observation (GIL, 1988).

\footnotetext{
${ }^{1}$ Original scientific contribution presented and discussed at XIV International Symposium on Scale Insect Studies, Catania-Italy, 13-16 June 2016.
}

The heterogeneity in populations of $P$. corni is also noted in both the sex ratio and its phenology. Such with others coccids, it is been reported that $P$. corni reproduces primarily by parthenogenesis rather than by sexual reproduction. The sex ratio in populations is extremely variable and apparently depends on the feeding conditions. In function of geographic location and host plants, P. corni display univoltinos behaviour in the northern Palearctic and develop up to three annual generations in the south to vary with the host plants (DANZIG, 1997).

Parthenolecanium corni exhibit the seasonal history and the spatial distribution of the most univoltine species of soft scale which overwinter as second-instar nymphs on the woody parts of trees. In general, in the spring, the secondinstar nymphs move onto branches or twigs where they moult into adult females. The females lay the eggs in a brood chamber beneath her abdomen. After hatching, the first-instar nymphs or crawlers move from beneath the female cover onto the plant surface where they disperse onto the new leaves, usually settling in clusters on the tips and along the outer margins on the topmost leaves. The intense activity of the crawlers can last several hours or even a few days. After settling and undergoing their first moult, the nymphs move less frequently. At the end of summer, the second-instar are mostly located on the lower surface of the leaves, stems or underside of the twigs. In the autumn, prior to leaf-fall, the second-instar nymphs migrate from the leaves to the woody parts of the plant to overwinter (MAROTTA \& TRANFAGLIA, 1997).

In Portugal, $P$. corni has been recorded in the vineyards since 1945 (CoutinHo, 1945). Subsequently, there is only 
reference to its presence in the north region (e.g., Douro) (CARLos et al., 2008) and, more recently, in the central region (e.g., Cadaval and Sardoal) (SILVA et al., 2014). However, although not quantified, there are several records of their resurgence. It may be explained by climate change, type of insecticides applied in the vineyard or even the practice of some cultural techniques. Recently, it became clear that some cultural techniques that modify notably the host microclimate level, in terms of temperature and relative humidity, such as pruning system may increase the occurrences of scale insects. SILVA et al. (2014) reported that mechanical pruning can induce a significant increase of the intensity of population of $P$. corni compared to the traditional manual pruning technique when the species is already present in vineyards. That may happen even after one year of implementation of this practice and the effect is most significantly when the number of years increases.

Thus, due to the increased importance of P. corni on vineyards, laboratory and field studies were addressed between 2012-2015 to improve the knowledge of some biological characters: i) identification and morphological characterization of soft scales in vineyards and the parasitoids associated; ii) seasonal development and life cycle; iii) reproduction.

\section{MATERIAL \& METHODS}

\section{IDENTIFICATION OF SPECIES (SOFT SCALE INSECT,} PARASITOIDS)

The collecting of specimens was carried out in two vineyards (Vitis vinifera L.) (Gradil: Aragonez e Syrah; Côro: Syrah) in the central region of Portugal (e.g., Cadaval and Sardoal) in the period of 2012-15. Some soft scale insects females were slide-mounted based on the method proposed by BEN-Dov \& HodgSON (1997) for systematic identification and Professor José Carlos Franco confirmed the identification according to the identification keys proposed by KoszTARAB (1996). Some soft scale insects females were maintaining for parasitoids' emergency in appropriated containers at lab conditions of isolation and the parasitoids species were identified by Dr. George Jasposhvil (Agricultural University of Georgia).

\section{Biological STUDiES}

Two bioassays were conducted in the laboratory (JuneOctober 2012, April-August 2015), using artificial infestation of P. corni in potted vines plants (2012: Aragonez, Syrah; 2015: Aragonez) under controlled conditions $\left(22^{\circ} \mathrm{C} \pm 2^{\circ} \mathrm{C}, 60 \% \pm 10 \%\right.$ h.r., $\left.14 \pm 1 \mathrm{~L}: 10 \pm 1 \mathrm{D}\right)$. The artificial infestation method used, similar to proposed by AFONSO et al. (2004), was performed collecting ovipositing females from the studied vineyards (2012: Gradil/Cadaval, Côro/Sardoal; 2015: Gradil), that were placed individually in shoots with the aid of a pin and cotton impregnated with water. After hatching, the first-instar nymphs or crawlers were observed twice weekly, using a stereomicroscope (1070x magnification; EMZ13TR Meiji Techno) and the place of a selected nymphs were marked and recorded by through the design of its position. It was conducted photographic record for each nymphal stage and for all observations (software ProgRes CT5 USB Color, Meiji Techno) under the same magnification (20x) for further characterization of the external morphology and determination of the dimensions (width, length). In parallel, field studies were conducted in both vineyards already described, monthly (spring to autumn) or bimonthly (winter) depending on the time of year in the period of 2012-2014. Observations were made to determine the state of development of P. corni and the spatial distribution (shoot, leaf, cluster) over time. Additionally, in 2015, it was determined the total number of eggs laid by the females according to the origin (e.g., Gradil/Cadaval, Côro/Sardoal) of the females, using a stereomicroscope.

\section{STATISTICAL ANALYSIS}

Analysis of variance (ANOVAs) were used to determine differences in both female dimensions (e.g., width, length) after molting, obtained in laboratory study carried out in 2012 and the total number of eggs laid by the females according to females origin (e.g., Gradil, Côro). Treatment means were separated using post-hoc multiple comparisons Tukey's HSD test. Data are presented as mean \pm SEM (standard error of the mean). The significance level was set at $\alpha=0.05$. All analyses were performed with SPSS 22.0 for Windows (SPSS Inc. Chicago, USA).

\section{RESULTS AND DISCUSSION}

IDENTIFICATION OF SPECIES (SOFT SCALE INSECT, PARASITOIDS)

The species of soft scale insects were confirmed as Parthenolecanium corni (Bouché, 1844). Coccophagus lycimnia (Walker, 1839) (Hymenoptera Aphelinidae) and Metaphycus dispar (Mercet, 1925) (Hymenoptera Encyrtidae) were identified as parasitoids associated with $P$. corni. Japoshvili et al. (2008) consider C. lycimnia one of the most common parasitoids associated to $P$. corni. To date, M. dispar was only found associated with Parthenolecanium persicae (Fabricius, 1776) (HOFFMAN \& SCHMUTTERER, 1999).

\section{BiologicAL STUDIES}

With respect to color nymphs, these are shown transparent in the first and second-instar, almost imperceptible. On the contrary, the third instar specimens have discolored brown with dark brown scores, like the branches where they settled. Adult females originating from Côro population have significantly higher length $\left(\mathrm{F}_{1 ; 18}=3.3, p<0.087\right)$ while no significant differences were found relative to the width $\left(\mathrm{F}_{1 ; 18}=1.66, p>0.22\right)$. The first-instar nymphs or crawlers move in the proximity of the phloem and preferentially colonizing the underside of the leaves. When complete the first molt, the second-instar nymphs migrate to the shoots. Mobility was detected throughout the entire duration of second-instar.

Based on observations of laboratory and field bioassay we can proposed the seasonal development and life cycle of $P$. corni observed in the studied vineyards. Parthenolecanium corni developed two nymphal instars before became adult female and two nymphal instars, followed by pupae before the emergence of the adult male. In winter, second-instar nymphs are settled in the cordon of vine plant (under the bark) and at the end of winter/begging of springer the sexual reproduction occurs. In late May, firstinstar nymphs begin to colonize the young leaves. The first and the second-instar nymphs remain in the leaves, although there is enough mobility. It was observed that in the late second instar, the leaves are no longer the preferred feeding place, probably because the typical nutritional decrease, and the nymphs migrate to the shoots on which can perforate the parenchyma through the stylets that are larger. At the end of the development period, the second-instar nymphs moves to 
various organs of the vine, particularly the leaves and clusters (berries and rachis) up to the time of the harvest, with high production of honeydew. Between the late spring and summer, the nymphs complete the second moult, reaching the adult female; in the meantime it is development of males due to the presence of pupae. At this time starts a reproduction cycle and the occurrence of firstinstar nymphs. In early autumn (the vine senescence time) beginning the migration of first and the second-instar nymphs to the cordon, being difficult to detection due the coloring similar to bark, where second-instar nymphs resist to winter weather. Parthenolecanium corni develops two annual generations, at least in the center of Portugal.

Due to the presence of male on the two reproduction periods, reproduction should be sexual (at least, facultative). The number of eggs laid per female ranged between 1444 and 3781 in females collected in Gradil $(\mathrm{N}=9)$, and between 267 and 4642 in females collected in Côro $(\mathrm{N}=9)$. On average, the average number of eggs laid by female differed significantly $(Z=6.917, P=0.018)$ in the two origins and was significantly higher in females collected in Côro. The observed fertility is compatible with the reference values for $P$. corni; depending on the size of the female, the P. corni fertility was recorded between 150 and 5000 eggs (MAROTTA, 1997)

\section{CONCLUSIONS}

We recorded the existence of some morphological differences and fertility levels recorded in the two regions studied, namely the higher length and higher fertility of females originating from Côro population. The differences may be to different grapevine varieties (e.g., Gradil: Aragonez; Côro: Syrah) as well as the environmental conditions to which the scales were subjected are different in the two regions and may constitute another example of differences in context of "the corni-complex" proposed by DANZIG (1997).

Based on laboratory and field bioassays undertaken corroborate some aspects of morphology as well the seasonal development and life cycle, reported in the literature by Danzig (1997) and MAROTTA \& TRANFAGLIA (1997), for populations of $P$. corni associated with vineyards.

For the reproduction, a better clarification is needed and, in the case of coexisting sexual and parthenogenetic reproduction, what their relative importance and under what conditions occur. The use of the molecular markers in case of $P$. corni may help to distinguish cryptic species in the studied populations.

\section{ACKNOWLEGMENTS}

This research was supported by Programa de Desenvolvimento Rural/PRODER (project FertilPoda, 4.1 “Cooperação para a Inovação" PRODER, P.A. 020397024071, partnership 397) and FCT: UID/AGR/00239/2013. Special thanks to Dr. George Jasposhvil (Agricultural University of Georgia) for parasitoids identification.

\section{REFERENCES}

Afonso A., Teixeira I., Botton M., Faria J., Loeck, A.E., 2004 - [Control of soft scale Parthenolecanium persicae (Fabricius, 1776) (Hemiptera: Coccidae) in vineyards]. Ciênc. Rural., 34(4): 985-989.

Ben-Dov Y., 1993 - A systematic Catalogue of the Mealybugs of the world (Insecta: Homoptera: Coccoidea: Pseudococcidae and Putoide) with data on geographical distribution, host plants, biology and economic importance. - Intercept, Andover. 536 pp.

Ben-Dov Y., Hodgson C.J., 1997 - Techniques. Colleting and Mounting. In: Ben-Dov Y. \& Hodgson C.J. Eds., Elsevier, Amsterdam, pp. 389-395.

CABI, 2016 - Invasive species compendium. Parthenolecanium corni (European fruit lecanium). http://www.cabi.org/isc/datasheet/45556 (referred to 19/08/2016).

DaAne K.M., CoOper M.L., Triapitsyn S.V., Walton V.M., Yokota Y.G., Haviland D.R., Bentley J.W., Godfrey K.E., Wunderlich L.R., 2008 - Vineyard managers and researchers seek sustainable solutions for mealybugs, a changing pest complex. - California Agric., 62: 4.

DANZIG E.M., 1997 - Intraspecific variations of taxonomic characters. In: Soft scale insects - Their biology, natural enemies and control, Ben-Dov Y. \& Hodgson C.J. Eds., Elsevier, Amsterdam, pp. 203-210.

GILL R.J., 1988 - The Scale Insects of California Part 1. The Soft Scale (Homoptera: Coccoidea: Coccidae). Technical Services in Agricultural Biosystematics and Plant Pathology, California Department of Food and Agriculture. 132 pp.

Hoffman V.C.H., Schmutterer H., 1999 - Die Pfirsichschildlaus Parthenolecanium persicae (F.) in Südbadeneinfür Deutschland neuer Schädling der Weinrebe Vitis vinifera L.- J. Pest Sci., 72: 52-54.

JAPOSHIVILI G., GABROSHVILI N., JAPSHVILI B., 2008 - The parasitoide complex of Parthenolecanium corni Bouché in the city of Tbilisi and its surroundings and comparasion with some other European countries. - Bull. Entomol. Res., 98: 53-56.

Marotta S., 1997 - Seasonal history; Diapause. In: BenDov \& Hodgson CJ (Eds.) Soft scale insects - Their biology, natural enemies and control. Elsevier, Amsterdam: 343-3505.

Marotta S., Tranfaglia A., 1997 - Biology. General life history. In: Soft scale insects - Their biology, natural enemies and control, Ben-Dov Y. \& Hodgson C.J. Eds., Elsevier, Amsterdam, pp. 251-255.

Silva E.B., Maia M., Lopes P., Cruz A., Botelho M., Franco J.C., MeXIA A., 2014 - [Mealybugs associated with vineyard: potential for interaction with type of pruning and organic fertilization]. X Encontro Nacional de Proteção Integrada. Beja (Portugal), 02-03 May 2014: 43.

Stathas G., Eliopoulos P.A., Bouras P.L., Economou L.P., Kontodimas D.C., 2003 - The scale Parthenolecanium persicae (Fabricius) on grapes in Greece. IOBC/EPRS working group, Integrated Protection and Production in Viticulture. Greece, Bull. IOBC/EPRS, 26(8): 253-257. 
